\title{
Influence of bio and mineral fertilization on some sesame varieties grown in Upper
}

\section{Egypt}

\author{
Attia, A.M. ${ }^{1 *}$ and A. Abd-El-Saber ${ }^{2}$
}

${ }^{1}$ Soils, Water and Environment Research Institute, Agriculture Research Center, Giza, Egypt.

${ }^{2}$ Field Crops Research Institute, Agricultural Research Center, Giza, Egypt.

\begin{abstract}
Nowadays, there is a call for the reduction of the environmental pollution resulted from over application of chemical fertilizers. Therefore, study has been done to investigate the possibility and efficiency of using bio-fertilizers. Two field experiments were carried out during the two successive summer growing seasons of 2016 and 2017 at El-Mattana, Agriculture Research Station (latitude of $25^{\circ} 17^{\prime} \mathrm{N}$ and longitude $32^{\circ} 33^{\prime} \mathrm{E}$ ), Luxor Governorate, Egypt to evaluate the influence of two sesame varieties (Sohag 1 and Shandaweel-3) and eight different fertilizers treatments: 0, 50, 75, 100\% of recommended nitrogen, phosphorus and potassium (NPK), bio-fertilizers, $50 \%$ NPK + bio, 75\% NPK+ bio and $100 \%$ NPK + bio on sesame yield. Treatments were carried out as Split Plot Design with three replicates, varieties in the main plots and fertilization treatments in the sub plots. The results could be summarized as follows: Shandaweel-3 variety surpassed Sohag-1 variety in all studied characters. Except umber of capsules/plants, length of fruiting area, harvest index, oil yield, K uptake in seed and NK uptake in straw. The addition of $100 \%$ mineral recommended dose of NPK + Bio fertilizer resulted in a significant increment in sesame yield and its components in both seasons. The highest oil yield and content of $\mathrm{N}$ and $\mathrm{P}$ were obtained from Shandaweel-3 with fertilization at 75\% NPK+ Bio-fertilization treatment. The results showed the importance of using bio-fertilizers to protect the soil and the environment from harmful chemical pollution.
\end{abstract}

Keywords: Sesame varieties yield; Upper Egypt; Nitrogen; Phosphorus, Potassium and bio fertilizer.

\section{Introduction}

Sesame being an important oilseed crop as it has its own merits like its fast growth rate, short duration, less water requirement, and wide adaptability under varying soil type. Sesame is an important oilseed crop with great commercial attributes by virtue of its oil having an edible quality and medicinal value. It yields $50-60 \%$ oil and

\footnotetext{
*Corresponding author: Attia, A.M

Email: awadattiaa@yahoo.com

Received: February 14, 2021;

Accepted: April 2, 2021;

Published: April 11, 2021.
}

the oil is highly stable against rancidity due to the presence of the natural antioxidants sesamin and sesamolin (Weiss, 2000 and El-Khier et al., 2008).

In Egypt, sesame is considered as a food crop rather than oilseed crop because most of its seeds production is used for snacks, confectionery, bakery products, tehena and halawa purposes. The cultivated area increased markedly during the last few years, while the productivity was not increased by the same relative. However, 
the local production of sesame did not cover the national requirements, thus a lot of amount of sesame seeds was imported every year. So increasing the productivity could be achieved through generate a new cultivars with high yield potentiality as well as application of suitable agricultural practices such as fertilization, irrigation and weed control etc. (El-Habbasha et al., 2007 and Abdo and Anton, 2009).

Sesame needs more nitrogen than any other nutrient to increase plant height, leaf area, dry matter and seed production (Purushottam, 2005). Studies have indicated that nitrogen, phosphorus and even potassium are the major nutrient elements influencing the growth and yield of sesame (Shehu, 2014).

One of the main bases in sustainable agriculture is application of biologic fertilizers in agronomical ecosystems to reduce consumption of chemical inputs so that they can guarantee production sustainability of agriculture systems in some cases as a substitution and as a supplement in majority of cases for chemical fertilizers (Antoun, H. 2005).

Biologic fertilizers consist of some beneficial microorganisms that are produced for specific purposes such as nitrogen fixation and releasing phosphate and potassium. These microorganisms usually are placed around the root helping the plant to nutrient uptake through cohabitation (Elkholy et al., 2005). These bacteria have more than one role so that they not only help to uptake a specific element but also can absorb other elements, reduce illnesses, improve soil structure, more promote plant growth, increase quantity and quality of product and increase plant tolerance against environmental stresses (Elkramany et al., 2007).

El-Samanody et al., (2010) and Amal et al., (2015) indicated that Shandaweel-3 gave the best results in all studied characters as well as the highest values of $\mathrm{N}, \mathrm{P}$ and $\mathrm{K}$ of the seed content. Biofertilizer led to a significant increase in yield components and yield, also N, P and $\mathrm{K}$ of sesame seeds. Shandaweel 3 was superior in seed yield by 10.30 and $5.90 \%$ as compared with Sohag1 in two seasons, respectively. Hamza and Abd El-Salam (2015) found that sesame variety Shandaweel-3 surpassed significantly on the Sohag-1 in number of fruiting nodes/ plant, number of capsules /plant, capsule length, number of seeds /capsule, 1000seed weight, seed weight/ plant, seed and oil yields /ha, as well as, harvest index.

Mahrous et al., (2015) showed that the cultivar Shandaweel-3 surpassed Toushka1 in plant height, seed weight per plant, 1000-seed weight and seed yield per feddan as well as oil and protein percentages. Treatment 100\% recommended chemical fertilizer + biofertilizer came in the first order for sesame attributes (plant height, seed weight per plant and 1000-seedweight). The effect of the interaction between the two commercial cultivars and fertilization treatments on seed yield per plant, seed yield per feddan, oil and/or protein percentages was significant in the two seasons except oil percentage had no significant in the second season. The results showed the importance of applying biofertilizers and bio agent chemical fertilizers to protect the environment from harmful chemical pollution.

Boghdady et al. (2012) revealed that increasing level of the used mineral 
fertilizers induced significant increases in all investigated morphological and yield characters as well as in seed oil percentage of sesame cv. Shandaweel-3. It is realized that raising the level of the used mineral fertilizers from 25 to $100 \%$ of the recommended dose induced prominent increases plant height, number of capsules/plant, weight of 1000 seeds, yield of seeds/plant and seed oil percentage; respectively. Data also indicated that sesame plants obtained from biofertilized seeds and grown in biofertilized soil showed prominent increases in all investigated morphological and yield characters as well as in seed oil percentage when compared with control plants which were obtained from uninoculated seeds and grown in uninoculated soil. Abdel-Rahman (2014) indicated the seed inoculation with bio fertilizer significantly affected the sesame yield and its contents of the studied nutritive elements.

Asl (2017) found that a significant effect of nitrogen and phosphate as biofertilizer,

\section{Materials and Methods}

Two field experiments were carried out during the two successive summer growing seasons of 2016 and 2017 at El-Mattana Agricultural Research Station, (latitude of 25.17o $\mathrm{N}$ and longitude 32.33o E), Luxor Governorate (Upper Egypt), to evaluate the effect of NPK fertilization (mineral on plant height, No. of branches/plant, No. of capsules/plant, seed in capsules, oil percent, seed yield and harvest index. Consumption of chemical fertilizer of triple super phosphate was reduced equal to $50 \%$ using phosphate biofertilizer and consumption of chemical fertilizer of urea was reduced equal to $25 \%$ using nitrogen biofertilizer. Elizabeth et al., (2017) indicated inoculated seeds with Phosphate Solubilizing Microorganisms (PSM) are a promising strategy to improve world food production without causing any environmental hazard. Heba et al., (2018) found that the soil treated with different sources and rates of potassium fertilizers with potassium solubilizing bacteria (KSB) led to decrease both soil $\mathrm{pH}$ and increased available $\mathrm{N}, \mathrm{P}$ and $\mathrm{K}$ in soil solutions. Heba et al., 2018. Hassaan, M. A. and A. M. Bughdady (2018) showed that Shandaweel 3 cultivar with bio-fertilizer produced the highest seed yield than Sohag1 cultivar under conditions of the Toshka, South Egypt

and bio-fertilizers) and two varieties of sesame: Sohag 1 and Shandaweel-3. Samples of soil were randomly taken from the field experiments and then analyzed for some soil physical and chemical characteristics according to the methods outlined by Black (1965) and Ryan et al. (1996) Table (1).

Table 1. some physical and chemical properties of the experiment soil before sowing.

\begin{tabular}{|c|c|c|c|c|c|c|c|c|c|c|c|}
\hline \multirow{2}{*}{ Properties } & \multicolumn{6}{|c|}{ Particle size distribution } & \multirow{2}{*}{$\begin{array}{c}\mathrm{OM} \\
\%\end{array}$} & \multirow{2}{*}{$\begin{array}{c}\mathrm{CaCO} 3 \\
\%\end{array}$} & \multirow{2}{*}{\multicolumn{2}{|c|}{$\mathrm{pH}$}} & \multirow{2}{*}{$\begin{array}{c}\mathrm{EC} \\
\mathrm{dSm}^{-1}\end{array}$} \\
\hline & & & Silt $\%$ & Clay $\%$ & Textur & ass & & & & & \\
\hline \multirow[t]{2}{*}{ Values } & & & 30.6 & 29.4 & Clay & & 0.73 & 2.5 & & & 2.5 \\
\hline & \multicolumn{6}{|c|}{ Soluble Cations and anions (meq/L) } & & & \multicolumn{3}{|c|}{$\begin{array}{c}\text { Available Nutrients } \\
\left(\mathrm{mg} \mathrm{kg}^{-1}\right)\end{array}$} \\
\hline Properties & $\mathrm{Ca}^{++}$ & $\mathrm{Mg}^{++}$ & $\mathrm{Na}^{+}$ & $\mathrm{K}^{+}$ & $\mathrm{CO}^{--}$ & $\mathrm{HCO}^{-}$ & $\mathrm{Cl}^{-}$ & $\mathrm{SO}^{--}$ & $\mathrm{N}$ & $\mathrm{P}$ & K \\
\hline Values & 7.1 & 4.8 & 12.1 & 1.0 & - & 1.0 & 19.4 & 4.6 & 40 & 7.3 & 232 \\
\hline
\end{tabular}


Experimental Design and Treatments: Split Plot Design with three replicates was utilized. Each experiment included 16 treatments, and the plot area was $10.5 \mathrm{~m}^{2}$ (five lines $* 3.5 \mathrm{~m}$ length $* 60 \mathrm{~cm}$ width). The main plots were arranged for two varieties of sesame: Sohag 1 and Shandaweel-3, and the sub plots were divided into eight treatments of NPK fertilization (mineral and bio fertilizers) as follows: without fertilization (control), $\mathrm{NPK} 130 \mathrm{~kg} \quad \mathrm{~N}, \quad 15 \mathrm{~kg} \quad \mathrm{P}_{2} \mathrm{O}_{5}$ and $24 \mathrm{~kg}$ $\mathrm{K}_{2} \mathrm{O} / \mathrm{fed}^{-1} \quad(50 \% \mathrm{NPK}), \mathrm{NPK} 245 \mathrm{~kg} \mathrm{~N}$, $22.5 \mathrm{~kg} \mathrm{P}_{2} \mathrm{O}_{5}$ and $36 \mathrm{~kg} \mathrm{~K}_{2} \mathrm{O}$ fed $^{-1}(75 \%$ NPK), NPK3 60kg N, 30kg $\mathrm{P}_{2} \mathrm{O}_{5}$ and $48 \mathrm{~kg}$ $\mathrm{K}_{2} \mathrm{O}$ fed $^{-1}$ (100\% NPK), Bio fertilization only, NPK1+ Bio fertilization, NPK2+ Bio fertilization and NPK3+ Bio fertilization.

Sesame seeds were sown on May $15^{\text {th }}$ and $11^{\text {th }}$ in the first and second seasons, respectively. The seeds of two varieties of sesame: Sohag 1 and Shandaweel-3 were coated just before sowing with bio fertilizers, using Arabic gum as an adhesive agent, and were sown at hills per $10 \mathrm{~cm}$. The seeds rate amounted $3 \mathrm{~kg} / \mathrm{fed}$. Soil application of nitrogen and potassium fertilizers as ammonium nitrate fertilizer $(33.5 \% \mathrm{~N})$ and potassium sulfate $(48 \%$ $\mathrm{K}_{2} \mathrm{O}$ ), were applied at two equal doses for all $\mathrm{N}$ and $\mathrm{K}$ fertilization treatments at 21 and 45 days after sowing, while phosphorus was added as calcium super phosphate $\left(\begin{array}{llll}15.5 & \% & \mathrm{P}_{2} \mathrm{O}_{5}\end{array}\right)$ with soil preparation. The bio-fertilizers used contain nitrogen fixer's bacteria Azotobacter or Azospirillum brasilense, phosphate dissolving bacteria (Bacillus megatherium) and potassium dissolving bacteria (Bacillus circulans) at the concentration of $9^{10}$ colony forming unit /g for each was used. The bio-fertilizers provided by the Unit of Bio-fertilizers
Production- Microbiology Research

Department- Soils, Water and Environment Res. Institute- Agric. Res. Center, Giza, Egypt.

The yield was harvested on September $10^{\text {th }}$ in 2016 and on September $15^{\text {th }}$ in 2017. Samples of 10 guarded plants were randomly taken from inner ridges in each sub plot to estimate plant height $(\mathrm{cm})$, number of capsules/plant, 1000 seed weight $(\mathrm{g})$, first capsule height $(\mathrm{cm})$, length of fruiting area $(\mathrm{cm})$, biological yield ( $\mathrm{kg} / \mathrm{fed}$.$) , seed yield ( \mathrm{kg} / \mathrm{fed}$.$) , straw yield$ (kg/fed.), harvest index\%. Oil yield $(\mathrm{kg} / \mathrm{fed})$, oil $(\%)$, seed protein \% were determined according to A.O.A.C. (1990). Protein content was calculated as follows: (Protein $\%=\mathrm{N} \%$ in grain $\times 5.30)$. Nitrogen was determined by Kjeldahl method, phosphorus was determined spectrophotometrically and potassium was determined using flame photometer.

\section{Results and Discussions:}

\section{Growth characters and yield attributes}

Data presented in Table (2) show differences between the two varieties of sesame (Sohag-1 and Shandaweel-3) in plant height, number of capsules/ plant, 1000-seed weight, first capsule height, first capsule height, length of fruiting area $(\mathrm{cm})$ and Biological yield ( $\mathrm{kg} / \mathrm{fed}$.). The data illustrate significant differences between the two varieties in all the above studied characters, variety Shandawel-3 tended to have high plant height, 1000-seed weight, first capsule height and biological yield/fad at harvest compared with Sohag-1 variety in two seasons. These results are in concert with those obtained by ElHabbasha, et al. (2007), El-Samanody et al., (2010), Amal et al., (2015) and Hamza and Abd El-Salam (2015). Shandaweel-3 
surpassed significantly on the Sohag-1 in number of fruiting nodes/ plant, number of capsules /plant, capsule length, number of seeds /capsule, 1000-seed weight, seed weight/ plant, seed and oil yields /ha, as well as, harvest index in both seasons.

Furthermore, data in Table 2 focus that the effect of mineral and bio- fertilization on plant height, number of capsules/ plant, number of branches / plant, length of the fruiting area and biological yield/fad. The treatment $100 \%$ of recommended mineral NPK3 $\left(60 \mathrm{~kg} \mathrm{~N}, 30 \mathrm{~kg} \mathrm{P}_{2} \mathrm{O}_{5}\right.$ and $48 \mathrm{~kg} \mathrm{~K} 2 \mathrm{O} /$ $\left.\mathrm{fed}^{-1}\right)+$ Bio fertilization records the highest values of plant height (186.6 and 165.6 $\mathrm{cm}$ ), number of capsules/ plant (131.0 and 134.9 capsules/ plant), 1000-seed weight (5.31 and $5.46 \mathrm{gm}$.), length of the fruiting area $(104.83$ and $115.83 \mathrm{~cm})$ and biological yield/fad (2496.6 and 2287.0). While, first capsule height recorded highest values $(82.37$ and $55.83 \mathrm{~cm})$ followed by the control without fertilization treatment in both seasons. The present results cleared that dual application of mineral fertilization and biofertilizers were better than addition of mineral fertilization alone. These results agreed with those obtained by Purushottam, (2005), El-Habbasha, et al. (2007) and Shehu, (2014). Bio-fertilizer strengths plant growth through increasing free phosphorus of soil so that more photosynthetic materials are produced in plant, the growth of vegetative buds is promoted and the number of branches in plant is increased.

Here too the interaction between two sesame varieties (Sohag-1 and Shandaweel-3) and chemical and biofertilization treatments on plant height, number of capsules/ plant, 1000-seed weight, first capsule height, length of the fruiting area and biological yield/fad. The use of $100 \%$ of recommended mineral NPK3 (60kg N, 30kg P2O5 and 48kg K2O $/$ fed-1) + Bio fertilization with Shandaweel-3 gave the highest values of plant height (206.0 and $181.6 \mathrm{~cm}), 1000$ seed weight (5.45 and $5.60 \mathrm{gm})$ and biological yield/fad (2499.5and2347.1kg/fed.) in both seasons. Where, the highest values of number of capsules/ plant was (144.6 and 156.4 capsules/ plant) and length of the fruiting area was (108.66 and $121.66 \mathrm{~cm})$ the use of $100 \%$ of recommended mineral NPK (60kg N, 30kg P2O5 and 48kg K2O / fed1) with Sohag 1. But the highest value of first capsule height was (108.0 and 78.66 $\mathrm{cm}$ ) with Sohag-1 and control (without fertilization treatment) in both seasons. These results agreed with those obtained by El-Samanody et al., (2010), Amal et al., (2015) and Hassaan, and Bughdady (2018).

\section{Yield and yield component}

Data in Table 3 reveal that the tested sesame genotypes varied in seed yield $\mathrm{kg} / \mathrm{fed}$, straw yield $\mathrm{kg} / \mathrm{fed}$, harvest index $\%$, oil yield/ fed, oil \% and seed protein \% in the 1st and 2nd seasons. Shandaweel-3 produced higher seeds yield, straw yield, and oil yield $\mathrm{kg} / \mathrm{fad}$., oil $\%$ and seed protein $\%$ than sohag-1. The superiority of Shandweel-3 may be due to the increase in 1000 -seed weight and seed weight plant. El-Samanody et al. (2010) found that the Shandaweel 3 was superior in seed yield during two seasons compared with sohag1. These results agreed with those obtained by Subrahmaniyan et al. (1999), El Karamany et al. (2000), El Naim et al. (2010), Abd El-Lattief (2015) and Fakhry (2016). 
It is clearly from the results in same Table that the effect of mineral and biofertilization treatments on seed yield /fed, straw yield /fed, harvest index \%, oil yield/fed, oil $\%$ and seed protein $\%$ Significant differences between the treatments. The maximum seeds yield and oil yield /fed in the first season were 628.5 and $291.8 \mathrm{~kg} / \mathrm{fed}$, respectively, which was fertilized by NPK3 $\left(60 \mathrm{~kg} \mathrm{~N}, 30 \mathrm{~kg} \mathrm{P}_{2} \mathrm{O}_{5}\right.$ and $\left.48 \mathrm{~kg} \mathrm{~K}_{2} \mathrm{O} / \mathrm{fed}^{-1}\right)+$ Bio fertilization. In the second season, the corresponding mean values (614.2 and $289.1 \mathrm{~kg} / \mathrm{fed}$.) were gained at NPK2 $(45 \mathrm{~kg} \mathrm{~N}, 22.5 \mathrm{~kg}$ $\mathrm{P}_{2} \mathrm{O}_{5}$ and $36 \mathrm{~kg} \mathrm{~K}_{2} \mathrm{O}$ fed $\left.^{-1}\right)+$ Bio fertilization. Also, NPK2 + Bio fertilization records the highest values in harvest index \% (35.07 and 40.15\%) and protein \% (22.47 and $22.66 \%$ ) in both seasons. Straw yield /fed (1868.2 and $1678.1 \mathrm{~kg} / \mathrm{fed}$.) was the highest with NPK3 (60kg N, 30kg $\mathrm{P}_{2} \mathrm{O}_{5}$ and $48 \mathrm{~kg} \mathrm{~K}_{2} \mathrm{O} / \mathrm{fed}^{-1}$ ) + Bio fertilization. Asl (2017) found that a significant effect of nitrogen and phosphate as biofertilizer on seed yield and harvest index. The highest values on oil \% was treatment Bio fertilization only (48.24 and 48.91) in both season. Boghdady et al. (2012) indicated that sesame plants obtained from biofertilized seeds increases in seed oil percentage when compared with control plants which were obtained from uninoculated seeds and the treatment 50\% NPK+biofertilizer recorded the highest protein percentage. However, oil percentage decreased with increasing levels of nitrogen, due to with higher application of $\mathrm{N}$ there was greater accumulation of protein that hinders the availability of carbohydrates for polymerization into fatty acids and thus leading to lower oil content into seed. Hasanpour, et al. (2012) showed that application of biofertilizer caused an increase in oil yield.

Concerning the interactions effect, data in Table 3 reveal that the interaction had a significant effect on seed yield /fed, straw yield /fed, harvest index \%, oil yield/ fed and seed protein $\%$. In general, maximum seed yield /fed (653.6 and $673.8 \mathrm{~kg} \mathrm{fed}^{-1}$ ), Harvest index\% (37.88 and $41.55 \%$ ), oil yield/fed (306.2 and $313.8 \mathrm{~kg} / \mathrm{fed}$.) and seeds protein percentage (23.96 and 23.06 $\%)$ were obtained from Shandaweel-3 variety supplying with NPK2 $(45 \mathrm{~kg} \mathrm{~N}$, $22.5 \mathrm{~kg} \mathrm{P}_{2} \mathrm{O}_{5}$ and $36 \mathrm{~kg} \mathrm{~K}_{2} \mathrm{O}$ fed $\left.^{-1}\right)+$ Bio fertilization treatment in the first and second season. While the highest mean of straw yield/fad (1871.6 and $1749.0 \mathrm{~kg} \mathrm{fed}^{-}$ $\left.{ }^{1}\right)$ was obtained at the interaction of Shandaweel-3 variety with the treatment of $100 \%$ recommended mineral NPK3 $(60 \mathrm{~kg}$ $\mathrm{N}, 30 \mathrm{~kg} \mathrm{P}_{2} \mathrm{O}_{5}$ and $\left.48 \mathrm{~kg} \mathrm{~K}_{2} \mathrm{O} / \mathrm{fed}^{-1}\right)+\mathrm{Bio}$ fertilization. Also, the highest mean of the highest percent of oil were obtained at the interaction of Shandaweel-3and Bio fertilization only (49.08 and $49.87 \%$ ) in the both seasons.

Boghdady et al. (2012) reported that Shandaweel-3 fertilized with 50\% NPK recorded the highest value of oil percentage and seed protein $\%$. Result of Mahrous et al., (2015) showed that the application of $100 \% \mathrm{NPK}+$ biofertilizers (BM, BC, BP) with shandawel-3 gave maximum seed weight plant ${ }^{-1}$ during both seasons. The highest seed yield was obtained from T5 $(100 \%$ NPK+ biofertilizer+ bioagent) followed by $\mathrm{T} 4$ $(100 \% \mathrm{NPK}+$ biofertilizer). These findings are in close conformity with the results of El Habbasha et al.

(2007) 
Table 2. Effect of varieties, fertilization treatments and interaction between varieties and fertilization treatments on growth attributes of sesame plants in 2016 and 2017 seasons.

\begin{tabular}{|c|c|c|c|c|c|c|c|c|c|c|c|c|c|}
\hline \multirow{2}{*}{\multicolumn{2}{|c|}{ Characters }} & \multicolumn{2}{|c|}{$\begin{array}{l}\text { Plant height } \\
\quad(\mathrm{cm})\end{array}$} & \multicolumn{2}{|c|}{$\begin{array}{c}\text { Number of } \\
\text { capsules/plant }\end{array}$} & \multicolumn{2}{|c|}{$\begin{array}{l}1000 \text { seed } \\
\text { weight }(\mathrm{g})\end{array}$} & \multicolumn{2}{|c|}{$\begin{array}{l}\text { First capsule } \\
\text { height }(\mathrm{cm})\end{array}$} & \multicolumn{2}{|c|}{$\begin{array}{l}\text { Length of fruiting } \\
\text { area }(\mathrm{cm})\end{array}$} & \multicolumn{2}{|c|}{$\begin{array}{l}\text { Biological yield } \\
\text { (kg/fed.) }\end{array}$} \\
\hline & & $\mathbf{1}^{\text {st }}$ & $2^{\text {nd }}$ & $1^{\text {st }}$ & $2^{\text {nd }}$ & $\mathbf{1}^{\text {st }}$ & $2^{\text {nd }}$ & $1^{\text {st }}$ & $2^{\text {nd }}$ & $1^{\text {st }}$ & $2^{\text {nd }}$ & $1^{\text {st }}$ & $2^{\text {nd }}$ \\
\hline \multicolumn{14}{|c|}{ Varieties } \\
\hline & Sohag 1 & 157.2 & 140.5 & 107.7 & 106.6 & 4.29 & 4.45 & 53.08 & 29.41 & 102.95 & 110.75 & 1873.2 & 1678.0 \\
\hline & handawel 3 & 188.0 & 166.8 & 90.0 & 82.6 & 4.52 & 4.70 & 97.37 & 68.50 & 89.25 & 97.83 & 1966.2 & 1878.8 \\
\hline & F test & $*$ & $*$ & $*$ & $*$ & $*$ & $*$ & $*$ & $*$ & $*$ & $*$ & $*$ & $*$ \\
\hline \multicolumn{14}{|c|}{ Fertilization treatments } \\
\hline & (Control) & 164.5 & 143.6 & 62.1 & 58.4 & 3.82 & 3.99 & 82.37 & 55.83 & 82.33 & 87.16 & 1210.2 & 967.8 \\
\hline & NPK1 & 173.6 & 155.0 & 95.0 & 86.4 & 4.00 & 4.17 & 77.50 & 50.50 & 98.00 & 103.66 & 1734.8 & 1753.3 \\
\hline & NPK2 & 171.8 & 153.1 & 99.6 & 95.5 & 4.46 & 4.61 & 72.16 & 45.33 & 99.66 & 107.50 & 2150.6 & 1873.9 \\
\hline & NPK3 & 180.0 & 162.6 & 113.6 & 113.8 & 4.88 & 5.10 & 76.83 & 53.50 & 98.83 & 108.83 & 2286.2 & 2010.0 \\
\hline & Bio. Only & 163.8 & 145.3 & 75.0 & 71.4 & 3.70 & 3.87 & 70.00 & 47.00 & 93.16 & 97.83 & 1139.2 & 1340.2 \\
\hline & NPK1+ Bio & 168.8 & 150.6 & 100.8 & 86.6 & 4.06 & 4.22 & 71.83 & 44.00 & 97.00 & 106.50 & 2018.7 & 1845.2 \\
\hline & NPK2+ Bio & 172.1 & 153.5 & 113.8 & 109.6 & 4.99 & 5.16 & 73.50 & 46.16 & 94.66 & 107.00 & 2321.1 & 2149.7 \\
\hline & NPK3+ Bio & 186.6 & 165.6 & 131.0 & 134.9 & 5.31 & 5.46 & 77.83 & 49.33 & 105.16 & 115.83 & 2496.6 & 2287.0 \\
\hline & $\mathrm{SD}$ at $0.05 \%$ & 5.9 & 6.68 & 8.7 & 7.4 & 0.20 & 0.06 & 6.62 & 4.02 & 9.11 & 7.92 & 252.7 & 151.7 \\
\hline \multicolumn{14}{|c|}{ Interaction of varieties $*$ fertilization } \\
\hline \multirow{8}{*}{ 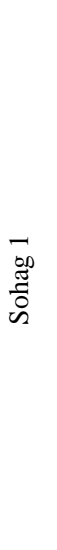 } & (Control) & 149.3 & 127.3 & 76.0 & 71.0 & 3.70 & 3.86 & 56.33 & 33.00 & 93.00 & 94.00 & 1172.1 & 950.9 \\
\hline & NPK1 & 161.3 & 144.6 & 94.3 & 85.7 & 3.88 & 4.05 & 57.00 & 34.66 & 108.00 & 109.33 & 1721.0 & 1752.5 \\
\hline & NPK2 & 156.3 & 140.3 & 106.6 & 104.5 & 4.56 & 4.74 & 48.00 & 25.66 & 108.33 & 114.00 & 2069.1 & 1825.6 \\
\hline & NPK3 & 166.0 & 153.6 & 122.3 & 122.3 & 4.70 & 4.90 & 57.00 & 38.66 & 102.00 & 114.66 & 2280.3 & 1973.8 \\
\hline & Bio. Only & 150.0 & 132.3 & 80.0 & 79.0 & 3.60 & 3.75 & 47.33 & 25.33 & 101.33 & 106.66 & 1032.2 & 1023.0 \\
\hline & $\begin{array}{l}\text { NPK1+ } \\
\text { Bio }\end{array}$ & 149.6 & 134.6 & 106.0 & 105.5 & 3.93 & 4.07 & 48.00 & 23.00 & 101.66 & 111.66 & 1958.7 & 1675.1 \\
\hline & $\begin{array}{c}\text { NPK2+ } \\
\text { Bio }\end{array}$ & 158.3 & 142.0 & 131.6 & 128.4 & 4.75 & 4.89 & 55.00 & 27.66 & 100.66 & 114.00 & 2258.7 & 1995.9 \\
\hline & $\begin{array}{c}\text { NPK3+ } \\
\text { Bio }\end{array}$ & 167.3 & 149.6 & 144.6 & 156.4 & 5.18 & 5.32 & 56.00 & 27.33 & 108.66 & 121.66 & 2493.8 & 2227.0 \\
\hline \multirow{8}{*}{ 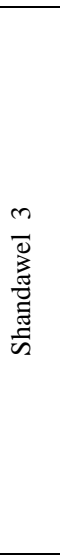 } & (Control) & 179.6 & 160.0 & 48.3 & 45.8 & 3.95 & 4.12 & 108.00 & 78.66 & 71.66 & 80.00 & 1248.3 & 984.8 \\
\hline & NPK1 & 186.0 & 165.3 & 95.6 & 87.2 & 4.13 & 4.30 & 98.00 & 66.33 & 88.00 & 98.00 & 1748.7 & 1754.1 \\
\hline & NPK2 & 187.3 & 166.0 & 92.6 & 86.5 & 4.36 & 4.48 & 96.33 & 65.00 & 91.00 & 101.00 & 2232.2 & 1922.2 \\
\hline & NPK3 & 194.0 & 171.6 & 105.0 & 105.4 & 5.07 & 5.31 & 96.33 & 68.33 & 95.66 & 103.00 & 2292.0 & 2046.2 \\
\hline & Bio. Only & 177.6 & 158.3 & 70.0 & 63.9 & 3.80 & 3.99 & 92.66 & 68.66 & 85.00 & 89.00 & 1246.3 & 1657.4 \\
\hline & $\begin{array}{l}\text { NPK1+ } \\
\text { Bio }\end{array}$ & 188.0 & 166.6 & 95.6 & 67.8 & 4.20 & 4.38 & 95.66 & 65.00 & 92.33 & 101.33 & 2078.7 & 2015.4 \\
\hline & $\begin{array}{c}\text { NPK2+ } \\
\text { Bio }\end{array}$ & 186.0 & 165.0 & 96.0 & 90.8 & 5.24 & 5.43 & 92.00 & 64.66 & 88.66 & 100.00 & 2383.9 & 2303.5 \\
\hline & $\begin{array}{c}\text { NPK3+ } \\
\text { Bio }\end{array}$ & 206.0 & 181.6 & 117.3 & 113.3 & 5.45 & 5.60 & 99.66 & 71.33 & 101.66 & 110.00 & 2499.5 & 2347.1 \\
\hline & SD at $0.05 \%$ & 8.4 & 9.45 & 12.1 & 10.4 & 0.29 & 0.09 & 9.36 & 5.68 & 12.89 & 11.21 & 357.3 & 214.5 \\
\hline
\end{tabular}


Table 3. Means of Yield (kg/fed.) and Some seeds chemical attributes as affected by genotypes, mineral and bio fertilization as well as their interactions in the sesame plants in 2016 and 2017 seasons.

\begin{tabular}{|c|c|c|c|c|c|c|c|c|c|c|c|c|c|}
\hline \multirow{2}{*}{\multicolumn{2}{|c|}{ Characters }} & \multicolumn{2}{|c|}{$\begin{array}{l}\text { Seed yield } \\
\text { (kg/fed.) }\end{array}$} & \multicolumn{2}{|c|}{$\begin{array}{c}\text { Straw yield } \\
\text { (kg/fed.) }\end{array}$} & \multicolumn{2}{|c|}{$\begin{array}{l}\text { Harvest } \\
\text { index } \%\end{array}$} & \multicolumn{2}{|c|}{$\begin{array}{l}\text { Oil yield } \\
\text { (kg/fed.) }\end{array}$} & \multicolumn{2}{|c|}{ Oil $(\%)$} & \multicolumn{2}{|c|}{$\begin{array}{c}\text { Seed protein } \\
\%\end{array}$} \\
\hline & & $1^{\text {st }}$ & $2^{\text {nd }}$ & $\mathbf{1}^{\text {st }}$ & $2^{\text {nd }}$ & $1^{\text {st }}$ & $2^{\text {nd }}$ & $\mathbf{1}^{\text {st }}$ & $2^{\text {nd }}$ & $1^{\text {st }}$ & $2^{\text {nd }}$ & $1^{\text {st }}$ & $2^{\text {nd }}$ \\
\hline \multicolumn{14}{|c|}{ Varieties } \\
\hline & Sohag 1 & 449.4 & 440.4 & 1423.7 & 1237.6 & 32.22 & 35.86 & 205.6 & 201.9 & 45.74 & 45.84 & 20.88 & 20.97 \\
\hline & Shandawel 3 & 473.2 & 485.3 & 1492.9 & 1393.5 & 31.75 & 34.67 & 217.3 & 223.5 & 46.10 & 46.02 & 22.08 & 21.57 \\
\hline & F test & ns & $*$ & $*$ & $*$ & $*$ & $*$ & $*$ & $*$ & ns & $*$ & $*$ & $*$ \\
\hline \multicolumn{14}{|c|}{ Fertilization treatments } \\
\hline & (Control) & 231.5 & 227.2 & 978.7 & 740.6 & 24.19 & 31.10 & 105.7 & 101.5 & 45.65 & 44.67 & 22.39 & 21.73 \\
\hline & NPK1 & 397.3 & 388.8 & 1337.6 & 1364.5 & 29.57 & 28.60 & 180.4 & 177.0 & 45.44 & 44.58 & 22.29 & 21.62 \\
\hline & NPK2 & 486.1 & 477.7 & 1664.5 & 1396.2 & 29.32 & 34.47 & 217.9 & 214.5 & 44.82 & 44.90 & 22.37 & 21.86 \\
\hline & NPK3 & 572.2 & 565.0 & 1714.0 & 1445.0 & 35.69 & 39.30 & 247.5 & 244.9 & 43.25 & 43.35 & 19.77 & 20.14 \\
\hline & Bio. Only & 310.3 & 373.9 & 828.9 & 966.3 & 38.11 & 39.87 & 149.7 & 183.5 & 48.24 & 48.91 & 21.33 & 20.94 \\
\hline & NPK1+ Bio & 462.6 & 447.0 & 1556.0 & 1398.2 & 29.98 & 32.15 & 215.6 & 207.8 & 46.60 & 46.35 & 20.94 & 19.74 \\
\hline & NPK2+ Bio & 602.3 & 614.2 & 1718.2 & 1535.5 & 35.07 & 40.15 & 282.8 & 289.1 & 46.97 & 47.13 & 22.47 & 22.66 \\
\hline & NPK3+ Bio & 628.5 & 608.9 & 1868.2 & 1678.1 & 33.82 & 36.51 & 291.8 & 283.4 & 46.44 & 46.53 & 19.56 & 21.47 \\
\hline & SD at $0.05 \%$ & 33.82 & 36.74 & 255.8 & 145.1 & 6.43 & 4.56 & 17.38 & 16.52 & 1.00 & 0.84 & 1.30 & 0.99 \\
\hline \multicolumn{14}{|c|}{ Interaction of varieties $*$ fertilization } \\
\hline \multirow{8}{*}{ 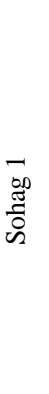 } & (Control) & 237.3 & 223.3 & 934.7 & 727.6 & 25.71 & 30.97 & 107.5 & 100.3 & 45.31 & 44.96 & 22.53 & 21.73 \\
\hline & NPK1 & 411.8 & 377.0 & 1309.2 & 1375.6 & 31.47 & 27.35 & 183.4 & 173.2 & 44.52 & 45.95 & 21.73 & 20.94 \\
\hline & NPK2 & 433.3 & 462.9 & 1635.8 & 1362.8 & 26.56 & 34.40 & 196.5 & 203.1 & 45.30 & 43.92 & 22.79 & 21.20 \\
\hline & NPK3 & 577.7 & 573.2 & 1702.6 & 1400.7 & 35.84 & 41.09 & 252.6 & 251.6 & 43.73 & 43.91 & 20.46 & 19.88 \\
\hline & Bio. Only & 299.3 & 306.3 & 732.8 & 716.7 & 41.47 & 43.49 & 141.8 & 146.9 & 47.40 & 47.96 & 21.20 & 21.47 \\
\hline & NPK1+ Bio & 455.8 & 406.1 & 1502.9 & 1268.9 & 30.57 & 32.25 & 208.0 & 183.0 & 45.67 & 45.04 & 18.82 & 19.08 \\
\hline & NPK2+ Bio & 551.1 & 554.6 & 1707.2 & 1441.3 & 32.27 & 38.75 & 259.5 & 264.4 & 47.10 & 47.68 & 20.99 & 22.26 \\
\hline & NPK3+ Bio & 629.0 & 619.7 & 1864.7 & 1607.3 & 33.90 & 38.66 & 295.4 & 293.1 & 46.96 & 47.29 & 18.02 & 21.20 \\
\hline \multirow{8}{*}{ 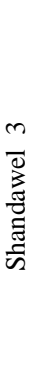 } & (Control) & 225.6 & 231.1 & 1022.6 & 753.7 & 22.66 & 31.22 & 103.8 & 102.6 & 45.99 & 44.37 & 22.26 & 21.73 \\
\hline & NPK1 & 382.7 & 400.6 & 1366.0 & 1353.5 & 28.02 & 29.85 & 177.3 & 180.9 & 46.35 & 45.21 & 22.84 & 22.31 \\
\hline & NPK2 & 538.9 & 492.5 & 1693.3 & 1429.7 & 32.08 & 34.55 & 239.3 & 226.0 & 44.34 & 45.88 & 22.68 & 22.53 \\
\hline & NPK3 & 566.7 & 556.8 & 1725.3 & 1489.4 & 35.55 & 37.52 & 242.5 & 238.3 & 42.87 & 42.80 & 19.08 & 20.41 \\
\hline & Bio. only & 321.3 & 441.4 & 925.0 & 1215.9 & 34.74 & 36.24 & 157.6 & 220.1 & 49.08 & 49.87 & 21.47 & 20.41 \\
\hline & NPK1+ Bio & 469.5 & 487.9 & 1609.1 & 1527.5 & 29.39 & 32.06 & 223.3 & 232.5 & 47.54 & 47.66 & 23.06 & 20.41 \\
\hline & NPK2+ Bio & 653.6 & 673.8 & 1730.3 & 1629.7 & 37.88 & 41.55 & 306.2 & 313.8 & 46.84 & 46.57 & 23.96 & 23.06 \\
\hline & NPK3+ Bio & 627.9 & 598.0 & 1871.6 & 1749.0 & 33.47 & 34.35 & 288.3 & 273.7 & 45.91 & 45.76 & 21.09 & 21.73 \\
\hline & D at $0.05 \%$ & 47.83 & 51.96 & 361.7 & 205.2 & 9.09 & 6.45 & 24.58 & 23.36 & 1.42 & 1.19 & 1.85 & 1.40 \\
\hline
\end{tabular}

NPK-Uptake (Kg fed $\left.{ }^{-1}\right)$ in seeds and straw

Data presented in Table (4) show that the varietal differences between two varieties of sesame (Sohag-1and Shandaweel 3) in NPK uptakes in seed and straw. Where, significant differences were observed between the two varieties in the studied characters except $\mathrm{P}$ and $\mathrm{K} \%$ in seed is no significant differences. However, Shandaweel 3 surpassed in NPK uptakes in 
seed and straw. El-Samanody et al., (2010) and Amal et al., (2015) indicated that Shandaweel-3 gave the best results in all studied characters as well as the highest values of $\mathrm{N}, \mathrm{P}$ and $\mathrm{K}$ of the seed content. Basavaraj et al., (2000) found that the concentration of $\mathrm{N}$ and $\mathrm{K}$ in seed did not differ significantly due to varieties.

According to the data presented in Table (4), average seeds and straw uptakes of the NPK were significantly differed between treatments fertilization. The superiority for the seeds and straw yield uptake of NPK was recorded for the treatment of $75 \%$ of recommended mineral (NPK2) $45 \mathrm{~kg} \mathrm{~N}$, $22.5 \mathrm{~kg} \mathrm{P}_{2} \mathrm{O}_{5}$ and $36 \mathrm{~kg} \mathrm{~K}_{2} \mathrm{O}$ fed $^{-1}+$ Bio fertilization. It increased by $12.55,5.34$, $6.01,31.24,45.04$ and $13.46 \%$ compared treatment $100 \%$ of recommended mineral NPK (60kg N, 30kg P2O5 and 48kg K2O / fed-1) for the average of the two seasons. El-Samanody et al., (2010) and Amal et al., (2015) indicated that bio-fertilizer led to a significant increase in yield components and yield, also N, P and $\mathrm{K}$ of the seeds of sesame in both seasons. The strength of relationship between seed yield and $\mathrm{N}, \mathrm{P}$ and $\mathrm{K}$ uptake was very strong. These results agreed with those obtained by Khaled et al., (2012), where the highest values of $\mathrm{N}, \mathrm{P}$ and $\mathrm{K}$ contents in seeds were $3.46,0.62$ and $1.07 \%$, respectively achieved by soil application of biofertilizer and organic materials could be used as an integrated plant nutrition with 20,30 or $40 \mathrm{~kg} \mathrm{fed}^{-1}$ of mineral $\mathrm{N}$. Moreover, application of such materials conserves the environment from chemical pollution hazards.

Concerning the interactions effects in this respect, data illustrated in Table 4 reveal that the interactions had a significant influence on NPK uptakes in seeds and straw. Thus, the highest average value of the seeds NPK uptake and P uptake of straw $\left(29.55,4.51\right.$ and $3.80 \mathrm{~kg} \mathrm{fed}^{-1}$ in the first season), $\left(25.05,5.08\right.$ and $4.20 \mathrm{~kg} \mathrm{fed}^{-1}$ in second seasons) and (7.54 and $5.75 \mathrm{~kg}$ fed $^{-1}$ in both seasons) were detected by Shandaweel-3 variety which was fertilized by $45 \mathrm{~kg} \mathrm{~N}, 22.5 \mathrm{~kg} \mathrm{P}_{2} \mathrm{O}_{5}$ and $36 \mathrm{~kg} \mathrm{~K}_{2} \mathrm{O}$ fed $^{-}$ $1+$ Bio fertilization .While the corresponding mean value in $\mathrm{K}$ uptake of straw $(27.89$ and $22.63 \mathrm{~kg} / \mathrm{fed}$. in both seasons) was recorded from Shandaweel-3 variety which was fertilized by $60 \mathrm{~kg} \mathrm{~N}$, $30 \mathrm{~kg} \mathrm{P}_{2} \mathrm{O}_{5}$ and $48 \mathrm{~kg} \mathrm{~K}_{2} \mathrm{O} / \mathrm{fed}^{-1}+$ Bio fertilization. However, the highest mean of the $\mathrm{N}$ uptakes in straw $\left(51.30 \mathrm{Kg} \mathrm{fed}^{-1}\right)$ were obtained at Sohag-1 variety which was fertilized by $45 \mathrm{~kg} \mathrm{~N}, 22.5 \mathrm{~kg} \mathrm{P}_{2} \mathrm{O}_{5}$ and $36 \mathrm{~kg} \mathrm{~K}_{2} \mathrm{O}$ fed $^{-1}+$ Bio fertilization in the first season. Also, as for the highest mean of the $\mathrm{N}$ uptakes in straw $\left(44,61 \mathrm{Kg} \mathrm{fed}^{-1}\right)$ were obtained at Shandaweel-3 variety which was fertilized by $(60 \mathrm{~kg} \mathrm{~N}, 30 \mathrm{~kg}$ $\mathrm{P}_{2} \mathrm{O}_{5}$ and $\left.48 \mathrm{~kg} \mathrm{~K}_{2} \mathrm{O} / \mathrm{fed}^{-1}\right)+$ Bio fertilization in the second season. ElHabbasha, et al., (2007) found that the interaction between two sesame varieties (Giza 32 and Shandawel 3) and partial replacement of chemical fertilizers by bioorganic fertilization treatments on NPK in seed. No significant differences were observed between treatments on the studied characters. The use of $75 \%$ chem. $+25 \%$ organic + biofertilizers with Shandaweel 3 gave the highest values of $P$ $\%$ in seed. However, the use of recommended chemical fertilization with Shandawel 3 and Giza 32 gave the highest values of $\mathrm{N} \%$ in seed in each variety, while the highest $\mathrm{K} \%$ in seed recorded by Shandawel 3 with the treatment $25 \%$ chem. $+75 \%$ organic + biofertilizers. 
Table 4. Effect of varieties, fertilization treatments and interaction between varieties on NPK-uptakes in seeds and straw yield (Kg fed-1) of sesame plants in 2016 and 2017 seasons.

\begin{tabular}{|c|c|c|c|c|c|c|c|c|c|c|c|c|c|}
\hline & & \multicolumn{6}{|c|}{ Uptake NPK in seed } & \multicolumn{6}{|c|}{ Uptake NPK in Straw } \\
\hline & \multirow[t]{2}{*}{ Characters } & \multicolumn{2}{|c|}{$\mathbf{N}$} & \multicolumn{2}{|c|}{$\mathbf{P}$} & \multicolumn{2}{|c|}{$\mathbf{K}$} & \multicolumn{2}{|c|}{$\mathbf{N}$} & \multicolumn{2}{|c|}{$\mathbf{P}$} & \multicolumn{2}{|c|}{$\mathbf{K}$} \\
\hline & & $1^{\text {st }}$ & $2^{\text {nd }}$ & $1^{\text {st }}$ & $2^{\text {nd }}$ & $1^{\text {st }}$ & $2^{\text {nd }}$ & $1^{\text {st }}$ & $2^{\text {nd }}$ & $1^{\text {st }}$ & $2^{\text {nd }}$ & $1^{\text {st }}$ & $2^{\text {nd }}$ \\
\hline \multicolumn{14}{|c|}{ Varieties } \\
\hline & Sohag 1 & 17.53 & 17.41 & 3.04 & 3.17 & 2.95 & 2.52 & 35.20 & 30.28 & 4.32 & 3.85 & 16.33 & 16.56 \\
\hline & Shandawel 3 & 19.70 & 19.71 & 3.10 & 3.18 & 2.85 & 2.89 & 34.66 & 31.91 & 4.51 & 4.27 & 20.87 & 17.42 \\
\hline & F test & $*$ & $*$ & n.s & n.s & n.s & $*$ & $*$ & $*$ & $*$ & $*$ & $*$ & $*$ \\
\hline \multicolumn{14}{|c|}{ Fertilization treatments } \\
\hline & (Control) & 9.78 & 9.31 & 1.42 & 1.28 & 1.42 & 1.34 & 21.05 & 15.85 & 1.77 & 1.24 & 9.57 & 8.51 \\
\hline & NPK1 & 16.68 & 15.83 & 2.66 & 2.74 & 2.44 & 2.38 & 32.13 & 32.13 & 3.51 & 3.59 & 17.50 & 18.44 \\
\hline & NPK2 & 21.19 & 19.38 & 3.25 & 3.52 & 2.82 & 2.76 & 41.38 & 33.93 & 5.66 & 5.05 & 21.91 & 17.45 \\
\hline & NPK3 & 21.37 & 22.86 & 3.86 & 4.24 & 3.64 & 3.27 & 37.34 & 31.44 & 4.99 & 4.64 & 21.44 & 19.34 \\
\hline & Bio. Only & 13.70 & 14.71 & 2.08 & 2.44 & 2.07 & 2.23 & 18.39 & 21.50 & 2.15 & 2.21 & 9.59 & 9.59 \\
\hline & NPK1+ Bio & 18.34 & 16.70 & 2.76 & 3.04 & 2.89 & 2.35 & 37.82 & 33.00 & 4.95 & 4.80 & 19.97 & 18.09 \\
\hline & NPK2+ Bio & 24.68 & 25.06 & 4.20 & 4.32 & 3.80 & 3.52 & 47.82 & 42.24 & 7.41 & 6.57 & 23.40 & 22.78 \\
\hline & NPK3+ Bio & 23.15 & 24.65 & 4.13 & 3.84 & 4.14 & 3.79 & 47.20 & 42.10 & 6.32 & 5.95 & 25.41 & 25.08 \\
\hline & LSD at $0.05 \%$ & 1.70 & 1.55 & 0.29 & 0.29 & 0.23 & 0.23 & 7.25 & 3.40 & 0.76 & 0.42 & 3.39 & 1.66 \\
\hline \multicolumn{14}{|c|}{ Interaction of varieties $*$ fertilization } \\
\hline \multirow{8}{*}{ 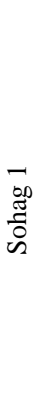 } & (Control) & 10.09 & 9.15 & 1.45 & 1.39 & 1.59 & 1.34 & 21.03 & 16.59 & 1.82 & 1.20 & 8.60 & 7.79 \\
\hline & NPK1 & 16.88 & 14.90 & 2.85 & 2.55 & 2.66 & 2.43 & 34.74 & 33.02 & 3.37 & 3.51 & 14.92 & 19.63 \\
\hline & NPK2 & 19.12 & 17.81 & 2.93 & 4.20 & 2.51 & 2.78 & 41.75 & 32.04 & 5.12 & 4.09 & 20.45 & 18.85 \\
\hline & NPK3 & 22.32 & 21.49 & 4.05 & 3.84 & 3.49 & 3.32 & 36.73 & 30.83 & 5.17 & 4.74 & 18.56 & 17.81 \\
\hline & Bio. Only & 14.37 & 12.41 & 2.06 & 2.24 & 2.07 & 1.91 & 16.88 & 17.20 & 1.75 & 1.66 & 7.62 & 7.51 \\
\hline & NPK1+ Bio & 16.24 & 14.62 & 2.58 & 2.94 & 3.05 & 1.99 & 34.69 & 32.61 & 5.44 & 4.79 & 17.73 & 15.29 \\
\hline & NPK2+ Bio & 19.82 & 24.16 & 3.90 & 3.56 & 3.80 & 2.84 & 51.30 & 41.82 & 7.28 & 6.30 & 19.80 & 23.15 \\
\hline & NPK3+ Bio & 21.39 & 24.79 & 4.17 & 4.65 & 4.49 & 3.59 & 47.56 & 39.65 & 6.19 & 6.12 & 22.94 & 27.24 \\
\hline \multirow{8}{*}{ 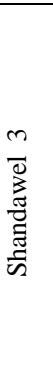 } & (Control) & 9.48 & 9.47 & 1.39 & 1.16 & 1.26 & 1.34 & 20.99 & 15.07 & 1.72 & 1.29 & 10.53 & 9.25 \\
\hline & NPK1 & 16.49 & 16.76 & 2.47 & 2.92 & 2.22 & 2.33 & 29.38 & 31.25 & 3.67 & 3.67 & 20.08 & 17.27 \\
\hline & NPK2 & 23.27 & 20.95 & 3.57 & 2.84 & 3.12 & 2.74 & 40.98 & 35.89 & 6.21 & 6.05 & 23.37 & 15.96 \\
\hline & NPK3 & 20.42 & 24.24 & 3.67 & 2.63 & 3.79 & 3.23 & 37.96 & 32.03 & 4.81 & 4.52 & 24.33 & 20.93 \\
\hline & Bio. only & 13.03 & 17.00 & 2.10 & 2.64 & 2.08 & 2.56 & 19.74 & 24.93 & 2.60 & 2.75 & 11.56 & 11.39 \\
\hline & NPK1+ Bio & 20.43 & 18.79 & 2.93 & 3.13 & 2.72 & 2.72 & 41.09 & 32.84 & 4.41 & 4.73 & 22.21 & 21.12 \\
\hline & NPK2+ Bio & 29.55 & 25.05 & 4.51 & 5.08 & 3.80 & 4.20 & 44.31 & 42.39 & 7.54 & 6.83 & 26.99 & 22.18 \\
\hline & NPK3+ Bio & 24.91 & 24.52 & 4.08 & 3.02 & 3.79 & 4.00 & 46.84 & 44.61 & 6.44 & 5.75 & 27.89 & 22.63 \\
\hline & LSD at $0.05 \%$ & 2.41 & 2.19 & 0.41 & 0.41 & 0.33 & 0.32 & 11.78 & 5.55 & 1.24 & 0.69 & 5.54 & 2.71 \\
\hline
\end{tabular}

\section{NPK percentage in seeds and straw}

Data exhibited in Table 4 reveal that the tested varieties of sesame varied significantly in seeds and straw content of $\mathrm{N}$ and $\mathrm{P}$ elements in both seasons. Thus, the maximum average values of seeds $\mathrm{N}$ content $(4.17$ and $4.07 \%$ in the two respective seasons) were recorded from Shandaweel 3 variety in both seasons. While, the maximum average values of seeds $\mathrm{p}$ content $(0.672$ and $0.666 \%$ in the two respective seasons) were recorded from Sohag-1 variety in both seasons. Also, the maximum average values of 
straw $\mathrm{N}$ content $(2.47$ and $2.29 \%$ in the two respective seasons) were recorded from Sohag-1 variety in both seasons. Here too, the obtained data in the same table revel that the $\mathrm{K}$ content of seeds and straw failed to be significant in this respect in both seasons. These results may be due to the differences among the examined varieties in their gene structure. These results are in harmony with those obtained by El-Habbasha, et al. (2007).

Also, the obtained data in the same table focus that N\&P content in sesame seeds and straw was reacted significantly to the tested NPK fertilization treatments in both seasons. The highest leaves mean values content of $\mathrm{N}$ (4.36 and $4.55 \%$ ) and in the first and second seasons, respectively) were obtained from sesame plants which were fertilized by NPK $2(45 \mathrm{~kg} \mathrm{~N}, 22.5 \mathrm{~kg}$ $\mathrm{P}_{2} \mathrm{O}_{5}$ and $36 \mathrm{~kg} \mathrm{~K}_{2} \mathrm{O}$ fed $^{-1}$. While, the highest leaves mean values content of $\mathrm{P}$ $(0.700$ and $0.707 \%)$ in the first and second seasons, respectively) were obtained from sesame plants which were fertilized by NPK2 $\left(45 \mathrm{~kg} \mathrm{~N}, 22.5 \mathrm{~kg} \mathrm{P}_{2} \mathrm{O}_{5}\right.$ and $36 \mathrm{~kg}$

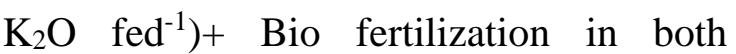
seasons. Similar observations were detected by El-Samanody et al., (2010) and Amal et al., (2015) who indicated that Biofertilizer led to a significant increase in $\mathrm{N}$, $\mathrm{P}$ and $\mathrm{K}$ of the seeds of sesame. Shehu et al., (2010) found the $\mathrm{N}$ fertilization enhanced N, P and K shoot uptake by 260 , 43 and 46\%, respectively. These results agreed with those obtained by Khaled $e t$ al. (2012), where the highest values of N, P and $\mathrm{K}$ contents in seeds were 3.46, 0.62 and $1.07 \%$, respectively achieved by soil application of bio-fertilizer and organic materials could be used as an integrated plant nutrition with 20,30 or $40 \mathrm{~kg} \mathrm{fed}^{-1}$ of mineral $\mathrm{N}$.
Regarding the interaction effects in this respect, data illustrated in Table 5 reveal that order interactions involved had a significant influence on NPK content of sesame seeds and straw trait in two seasons. Thus, Sohag-1 variety which was fertilized by $45 \mathrm{~kg} \mathrm{~N}, 22.5 \mathrm{~kg} \mathrm{P}_{2} \mathrm{O} 5$ and $36 \mathrm{~kg} \mathrm{~K}_{2} \mathrm{O}$ fed $^{-1}+$ Bio fertilization gave the highest average values of $\mathrm{P}$ percentage in seeds (0.711 and $0.712 \%)$ and $\mathrm{N}$ percentage in straw (3.01 and $2.90 \%$ ) in the two respective seasons).

\section{Soil fertility}

Data in Table 6 showed that Inoculated plants of sesame at sowing with bio-NPK fertilizer had positive effect on soil fertility, where it increased soil content of available $\mathrm{N}, \mathrm{P}$ and $\mathrm{K}$ that increasing the application rate of mineral NPK fertilizer significantly enhanced soil content of available $\mathrm{N}, \mathrm{P}$ and $\mathrm{K}$ as compared with control (without addition). No significant differences were observed between the two sesame varieties ((Sohag-1 and Shandaweel-3)) in soil content of available $\mathrm{N}, \mathrm{P}$ and $\mathrm{K}$ that increasing the application rate of mineral NPK fertilizer.

At the time of sowing $\mathrm{N}$ level in soil was $40 \mathrm{mg} \mathrm{kg}^{-1}$, P level was $7.3 \mathrm{mg} \mathrm{kg}^{-1}$ and $\mathrm{K}$ level was $232 \mathrm{mg} \mathrm{kg}^{-1}$. NPK levels in soil at time of harvesting was $66.3 \mathrm{mg} \mathrm{kg}^{-1}, \mathrm{P}$ level was $8.8 \mathrm{mg} \mathrm{kg-1and} \mathrm{K} \mathrm{level} \mathrm{was} 263$ $\mathrm{mg} \mathrm{kg}^{-1}$, when maximum in treatment NPK3 $60 \mathrm{~kg} \mathrm{~N}, 30 \mathrm{~kg} \mathrm{P}_{2} \mathrm{O}_{5}$ and $48 \mathrm{~kg} \mathrm{~K}_{2} \mathrm{O}$ $\mathrm{fed}^{-1}(100 \% \mathrm{NPK})+$ bio fertilizer. NPK + Biofertilizers improved the NPK status of the soil due to $\mathrm{N}$ fixation by Azotobacter and Azospirillum. Thus, improved the nitrogen availability in the soil improved the phosphorus status in the soil. Phosphorus soluble bacteria (PSB) solubilize the unavailable form of 
phosphorus into available form; also potassium soluble bacteria (KSB) solubilize the unavailable form of potassium into available form.
Biofertilization had moderately enhanced the fertility level of the soil after sesame harvest.

Table 5. Effect of varieties, fertilization treatments and interaction between varieties on NPK\% in seeds and straw yield (Kg fed-1) of sesame plants in 2016 and 2017 seasons.

\begin{tabular}{|c|c|c|c|c|c|c|c|c|c|c|c|c|}
\hline & \multicolumn{6}{|c|}{ NPK in seed } & \multicolumn{6}{|c|}{ NPK in Straw } \\
\hline Characters & \multicolumn{2}{|l|}{$\mathrm{N}$} & \multicolumn{2}{|c|}{$\mathrm{P}$} & \multicolumn{2}{|l|}{$\mathrm{K}$} & \multicolumn{2}{|c|}{$\mathrm{N}$} & \multicolumn{2}{|c|}{$\mathrm{P}$} & \multicolumn{2}{|c|}{$\mathrm{K}$} \\
\hline & $1^{\text {st }}$ & $2^{\text {nd }}$ & $1^{\text {st }}$ & $2^{\text {nd }}$ & $1^{\mathrm{st}}$ & $2^{\text {nd }}$ & $1^{\text {st }}$ & $2^{\text {nd }}$ & $1^{\text {st }}$ & $2^{\text {nd }}$ & $1^{\text {st }}$ & $2^{\text {nd }}$ \\
\hline \multicolumn{13}{|c|}{ Varieties } \\
\hline Sohag 1 & 3.99 & 3.96 & 0.672 & 0.666 & 0.65 & 0.58 & 2.47 & 2.45 & 0.303 & 0.311 & 1.13 & 1.34 \\
\hline Shandawel 3 & 4.17 & 4.07 & 0.650 & 0.655 & 0.60 & 0.59 & 2.32 & 2.29 & 0.302 & 0.307 & 1.37 & 1.25 \\
\hline F test & $*$ & $*$ & $*$ & $*$ & n.s & n.s & $*$ & $*$ & n.s & n.s & n.s & n.s \\
\hline \multicolumn{13}{|c|}{ Fertilization treatments } \\
\hline (Control) & 4.23 & 4.10 & 0.616 & 0.614 & 0.61 & 0.59 & 2.15 & 2.14 & 0.181 & 0.168 & 0.98 & 1.15 \\
\hline NPK1 & 4.21 & 4.08 & 0.670 & 0.678 & 0.61 & 0.61 & 2.40 & 2.35 & 0.263 & 0.263 & 1.31 & 1.35 \\
\hline NPK2 & 4.36 & 4.55 & 0.672 & 0.679 & 0.58 & 0.58 & 2.49 & 2.43 & 0.340 & 0.362 & 1.32 & 1.25 \\
\hline NPK3 & 3.73 & 4.05 & 0.675 & 0.689 & 0.64 & 0.58 & 2.18 & 2.18 & 0.291 & 0.321 & 1.25 & 1.34 \\
\hline Bio. only & 4.42 & 3.95 & 0.672 & 0.633 & 0.67 & 0.60 & 2.22 & 2.23 & 0.260 & 0.229 & 1.15 & 0.99 \\
\hline NPK1+ Bio & 3.95 & 3.73 & 0.627 & 0.634 & 0.63 & 0.52 & 2.43 & 2.36 & 0.318 & 0.344 & 1.28 & 1.29 \\
\hline NPK2+ Bio & 4.07 & 4.10 & 0.700 & 0.707 & 0.64 & 0.57 & 2.78 & 2.75 & 0.431 & 0.428 & 1.36 & 1.48 \\
\hline NPK3+ Bio & 3.69 & 4.05 & 0.658 & 0.648 & 0.66 & 0.62 & 2.53 & 2.51 & 0.338 & 0.355 & 1.36 & 1.49 \\
\hline LSD at $0.05 \%$ & 0.24 & 0.18 & 0.03 & 0.032 & 0.03 & 0.01 & 0.21 & 0.09 & 0.030 & 0.030 & 0.07 & 0.03 \\
\hline \multicolumn{13}{|c|}{ Interaction of varieties $*$ fertilization } \\
\hline (Control) & 4.25 & 4.10 & 0.614 & 0.622 & 0.67 & 0.60 & 2.25 & 2.28 & 0.195 & 0.164 & 0.92 & 1.07 \\
\hline NPK1 & 4.10 & 3.95 & 0.693 & 0.677 & 0.65 & 0.65 & 2.65 & 2.40 & 0.257 & 0.256 & 1.14 & 1.43 \\
\hline NPK2 & 4.40 & 3.85 & 0.677 & 0.710 & 0.58 & 0.60 & 2.55 & 2.35 & 0.313 & 0.300 & 1.25 & 1.38 \\
\hline NPK3 & 3.86 & 3.75 & 0.701 & 0.706 & 0.60 & 0.58 & 2.16 & 2.20 & 0.303 & 0.339 & 1.09 & 1.27 \\
\hline Bio. Only & 4.80 & 4.05 & 0.691 & 0.632 & 0.69 & 0.62 & 2.30 & 2.40 & 0.239 & 0.232 & 1.04 & 1.05 \\
\hline NPK1+ Bio & 3.55 & 3.60 & 0.627 & 0.626 & 0.67 & 0.50 & 2.31 & 2.57 & 0.362 & 0.377 & 1.18 & 1.20 \\
\hline NPK2+ Bio & 3.61 & 4.35 & 0.711 & 0.712 & 0.69 & 0.51 & 3.01 & 2.90 & 0.426 & 0.437 & 1.16 & 1.61 \\
\hline NPK3+ Bio & 3.40 & 4.00 & 0.664 & 0.642 & 0.71 & 0.57 & 2.55 & 2.47 & 0.332 & 0.381 & 1.23 & 1.69 \\
\hline (Control) & 4.20 & 4.10 & 0.617 & 0.607 & 0.56 & 0.58 & 2.05 & 2.00 & 0.168 & 0.172 & 1.03 & 1.23 \\
\hline NPK1 & 4.31 & 4.21 & 0.646 & 0.678 & 0.58 & 0.58 & 2.15 & 2.31 & 0.268 & 0.271 & 1.47 & 1.28 \\
\hline NPK2 & 4.32 & 4.25 & 0.667 & 0.648 & 0.58 & 0.56 & 2.42 & 2.51 & 0.367 & 0.423 & 1.38 & 1.12 \\
\hline NPK3 & 3.60 & 4.35 & 0.648 & 0.671 & 0.67 & 0.58 & 2.20 & 2.15 & 0.279 & 0.303 & 1.41 & 1.41 \\
\hline Bio. only & 4.05 & 3.85 & 0.654 & 0.634 & 0.65 & 0.58 & 2.13 & 2.05 & 0.281 & 0.226 & 1.25 & 0.94 \\
\hline NPK1+ Bio & 4.35 & 3.85 & 0.626 & 0.642 & 0.58 & 0.55 & 2.55 & 2.15 & 0.274 & 0.310 & 1.38 & 1.38 \\
\hline NPK2+ Bio & 4.52 & 3.85 & 0.690 & 0.701 & 0.58 & 0.62 & 2.56 & 2.60 & 0.435 & 0.419 & 1.56 & 1.36 \\
\hline NPK3+ Bio & 3.98 & 4.10 & 0.652 & 0.655 & 0.60 & 0.67 & 2.50 & 2.55 & 0.344 & 0.329 & 1.49 & 1.29 \\
\hline LSD at $0.05 \%$ & 0.34 & 0.26 & 0.05 & 0.05 & 0.05 & 0.01 & & 0.12 & 0.05 & 0.05 & 0.10 & 0.05 \\
\hline
\end{tabular}


Table 6. Effect of applied mineral and bio fertilizers on the availability of some macronutrient contents in soils $\left(\mathrm{mg} \mathrm{kg}^{-1}\right)$ after sesame varieties (combined data of 2016 and 2017 seasons.

\begin{tabular}{|c|c|c|c|c|}
\hline \multicolumn{5}{|c|}{ Available macronutrients (NPK) in soil $\left(\mathrm{mg} \mathrm{kg}^{-1}\right)$} \\
\hline \multicolumn{2}{|c|}{ Characters } & $\mathbf{N}$ & $\mathbf{P}$ & $\mathbf{K}$ \\
\hline \multicolumn{5}{|c|}{ Varieties } \\
\hline \multicolumn{2}{|c|}{ Sohag 1} & 50.16 & 7.83 & 247.16 \\
\hline \multicolumn{2}{|c|}{ Shandawel 3} & 51.20 & 7.97 & 248.41 \\
\hline \multicolumn{2}{|c|}{ F test } & n.s & n.s & n.s \\
\hline \multicolumn{5}{|c|}{ Fertilization treatments } \\
\hline \multicolumn{2}{|c|}{ (Control) } & 28.33 & 6.55 & 216.66 \\
\hline \multicolumn{2}{|c|}{ NPK1 } & 41.66 & 7.44 & 226.50 \\
\hline \multicolumn{2}{|c|}{ NPK2 } & 47.50 & 7.76 & 243.00 \\
\hline \multicolumn{2}{|c|}{ NPK3 } & 46.00 & 7.64 & 258.00 \\
\hline \multicolumn{2}{|c|}{ Bio. Only } & 52.50 & 8.00 & 245.00 \\
\hline \multicolumn{2}{|c|}{ NPK1+ Bio } & 59.66 & 8.31 & 264.5 \\
\hline \multicolumn{2}{|c|}{ NPK2+ Bio } & 63.50 & 8.62 & 265.66 \\
\hline \multicolumn{2}{|c|}{ NPK3+ Bio } & 66.33 & 8.87 & 263.00 \\
\hline \multicolumn{2}{|c|}{ LSD at $0.05 \%$} & 20.91 & $\mathbf{1 . 8 3}$ & 28.51 \\
\hline \multicolumn{5}{|c|}{ Interaction of varieties * fertilization } \\
\hline \multirow{8}{*}{ 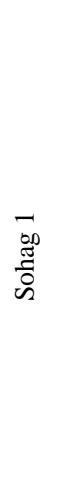 } & (Control) & 28.33 & 6.55 & 216.66 \\
\hline & NPK1 & 44.33 & 7.44 & 234.00 \\
\hline & NPK2 & 46.00 & 7.63 & 248.00 \\
\hline & NPK3 & 45.00 & 7.76 & 255.00 \\
\hline & Bio. Only & 50.66 & 7.88 & 239.00 \\
\hline & NPK1+ Bio & 58.66 & 8.17 & 261.66 \\
\hline & NPK2+ Bio & 62.66 & 8.45 & 261.66 \\
\hline & NPK3+ Bio & 65.66 & 8.72 & 261.33 \\
\hline \multirow{8}{*}{ 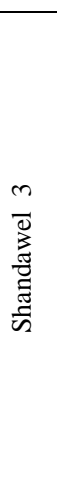 } & (Control) & 28.33 & 6.55 & 216.33 \\
\hline & NPK1 & 39.00 & 7.44 & 219.00 \\
\hline & NPK2 & 49.00 & 7.90 & 238.00 \\
\hline & NPK3 & 47.00 & 7.53 & 261.00 \\
\hline & Bio. Only & 54.33 & 8.12 & 251.00 \\
\hline & NPK1+ Bio & 60.66 & 8.44 & 267.33 \\
\hline & NPK2+ Bio & 64.33 & 8.79 & 269.66 \\
\hline & NPK3+ Bio & 67.00 & 9.02 & 264.66 \\
\hline & $.05 \%$ & 29.5 & n.s & 40.3 \\
\hline
\end{tabular}




\section{Economical evaluation}

Data in Table 7 show the economical evaluation of sesame yields (grain and straw) as affected by NPK fertilization treatments. The inputs were $200 \mathrm{~L} . \mathrm{E} / 50 \mathrm{~kg}$ ammonium nitrate fertilizer, $500 \mathrm{~L} . \mathrm{E} / 50 \mathrm{~kg}$ potassium sulfate $\left(48 \% \mathrm{~K}_{2} \mathrm{O}\right), 80 \mathrm{~L} . \mathrm{E} / 50$ $\mathrm{kg}$ calcium super phosphate $\left(15.5 \% \mathrm{P}_{2} \mathrm{O}_{5}\right)$, 30 L.E/biofertilizer and. The outputs were 22 L.E/kg grain (2728 L.E/ardab) and 500 L.E/1000 $\mathrm{kg}$ straw. Data illustrate that treatment of NPK3 +bio had the highest cost (2066 L.E), while the treatment of control had the lowest cost ( 0 L.E). For the total gross return per feddan, NPK3 +bio recorded the highest value (14498 L.E) of grain and straw yields. However, for the net return (total gross return - total cost), NPK2 $45 \mathrm{~kg} \mathrm{~N}, 22.5 \mathrm{~kg} \mathrm{P} \mathrm{O}_{5}$ and $36 \mathrm{~kg} \mathrm{~K}_{2} \mathrm{O}$ $\mathrm{fed}^{-1}(75 \% \mathrm{NPK})+$ Bio fertilization recorded the highest net return (12638 L.E). These results illustrate that NPK2 $45 \mathrm{~kg} \mathrm{~N}, 22.5 \mathrm{~kg} \mathrm{P}_{2} \mathrm{O}_{5}$ and $36 \mathrm{~kg} \mathrm{~K}_{2} \mathrm{O}$ fed $^{-1}$ $(75 \% \mathrm{NPK})+$ inoculation with biofertilizer was maximized grain and straw yields and the net return per feddan as compared with mineral fertilization at NPK3 $60 \mathrm{~kg} \mathrm{~N}$, $30 \mathrm{~kg} \mathrm{P}_{2} \mathrm{O}_{5}$ and $48 \mathrm{~kg} \mathrm{~K} \mathrm{~K}_{2} \mathrm{O}$ fed $^{-1}(100 \%$ NPK), (11263 L.E) and other treatments.

Table 7. Economical evaluation of sesame yield as affected by NPK fertilization treatments (average of two seasons).

\begin{tabular}{|c|c|c|c|c|c|c|c|}
\hline \multirow{2}{*}{ Treatments } & \multirow{2}{*}{$\begin{array}{c}\text { Total cost of } \\
\text { fertilization (L.E) }\end{array}$} & \multicolumn{2}{|c|}{ sesame yield $\left(\mathrm{kg} \mathrm{fed}^{-1}\right)$} & \multicolumn{3}{|c|}{ Gross Return (L.E) } & \multirow{2}{*}{$\begin{array}{l}\text { Net } \\
\text { return } \\
\text { (L.E) }\end{array}$} \\
\hline & & Grain & Straw & $\begin{array}{l}\text { Grain } \\
\text { yield }\end{array}$ & $\begin{array}{l}\text { Straw } \\
\text { Yield }\end{array}$ & Total & \\
\hline (Control) & 0 & 229.4 & 859.7 & 5046 & 430 & 5476 & 5476 \\
\hline NPK1 & $358+160+500)=1018$ & 393.1 & 1351.1 & 8647 & 676 & 9323 & 8305 \\
\hline NPK2 & $(537+240+750)=1527$ & 481.9 & 1530.4 & 10602 & 765 & 11367 & 9840 \\
\hline NPK3 & $(716+320+1000)=2036$ & 568.6 & 1579.5 & 12509 & 790 & 13299 & 11263 \\
\hline Bio. Only & 30 & 342.1 & 897.6 & 7526 & 449 & 7975 & 7945 \\
\hline NPK1+ Bio & $358+160+500+30)=1048$ & 454.8 & 1477.1 & 10006 & 739 & 10744 & 9696 \\
\hline NPK2+ Bio & $(537+240+750+30)=1557$ & 608.3 & 1626.9 & 13382 & 813 & 14195 & 12638 \\
\hline NPK3+ Bio & $(716+320+1000+30)=2066$ & 618.7 & 1773.2 & 13611 & 887 & 14498 & 12432 \\
\hline
\end{tabular}

\section{Conclusion}

From previous results, it can conclude to maximize yield of sesame varieties plant grown in Luxor governorate (Upper Egypt): fertilize plants with mineral fertilizers at rate of $45 \mathrm{~kg} \mathrm{~N}, 22.5 \mathrm{~kg} \mathrm{P}_{2} \mathrm{O}_{5}$ and $36 \mathrm{~kg} \mathrm{~K}_{2} \mathrm{O}$ fed $^{-1}$ (75\% NPK) with biofertilization and sowing sesame variety Shandaweel-3.

\section{References}

Abd El-Lattief, E.A. (2015) 'Impact of irrigation interval on productivity of sesame under southern egypt conditions' International J. of Advanced Res. In Eng. and App. Sci., 4 (10), pp.1-9.

Abdel-Rahman, A.H. (2014) 'Effect of mineral potassium, compost and biofertilizers on soil physio-chemical properties and productivity of 
sesame grown on salt affected soil' J. Soil Sci. and Agric. Eng., Mansoura Univ., 5 (6), pp. 791-805.

Abdo Fatma, A. (2008) 'Effect of phosphate dissolving bacteria inoculation and phosphorus fertilization on growth, yield and seed quality of soybean. Egypt' $J$. Agric. Res., 86(3), pp. 985-1009.

Ahmed, A.G., Hassanein, M.S., Zaki, N.M., Khalifa, R.K.M. and Badr, E.A. (2015) 'Effect of bio-NP fertilizer on yield, yield components and some biochemical components of two sesame varieties' Middle East J. Appl. Sci, 5(3), pp.630-635.

Antoun, H. (2005) 'Field and greenhouse trials performed with phosphate solubilizing bacteria and fungi. department of soil and agrifood engineering' Faculty of Agriculture and Food. Science, Canada, 8 p.

Antoun, L.W., Zakaria, S.M. and Rafla, H.H. (2010) 'Influence of compost, $\mathrm{N}$-mineral and humic acid on yield and chemical composition of wheat plants', Journal of Soil Sciences and Agricultural Engineering, 1(11), pp.1131-1143.

Asl, A.N. (2017) 'Effects of nitrogen and phosphate biofertilizers on morphological and agronomic characteristics of sesame (Sesamum indicum L.)' Open Journal of Ecology, (7), pp. 101-111.

A.O.A.C. (1990) 'Official methods of analysis of the association of official analytical chemists' $15^{\text {th }}$ (edition, published by Association of Official Analytical Chemists Arlington, Virginia U.S.A.).

Basavaraj, B., Shetty, R.A., Patil, S.G. and Hunshal, C.S. (2000) 'Nutrient content and upake by sesame varieties as influenced by fertilizer and population levels under summer irrigated conditions' Karnataka Journal of Agricultural Sciences, 13(1), pp.141-143.

Black, C.A. (1965) 'Methods of soil analysis' part 1. ASA Inc. Publisher, Madison, Wisconsin, USA. Agronomy, 9, pp.383-390.

Boghdady, M. S., Rania, M.A.N. and Fouad, A.A. (2012) 'Response of sesame plant (Sesamum orientale L.) to treatments with mineral and biofertilizers' Res. J. of Agric. and Biological Sci., 8(2), pp. 127-137.

El Naim, M.A., Mahmoud, F.A. and Khalid A.I. (2010) 'Effect of irrigation and cultivar on seed yield, yield's components and harvest index of Sesame (Sesamum indicum L.) 'Res. J. of Agri. and Biol. Sci., 6, pp. 492-497.

El-Habbasha, S.F., Abd El Salam, M.S. and Kabesh, M.O. (2007) 'Response of two sesame varieties (sesamum indicum 1.) to partial replacement of chemical fertilizers by bio-organic fertilizers' Research Journal of Agriculture and Biological Sciences, 3(6), pp. 563-571.

Alori, E.T., Glick, B.R. and Babalola, O.O. (2017) 'Microbial phosphorus solubilization and its potential for use in sustainable agriculture' Frontiers in microbiology, 8, p.971. doi: 10.3389/fmicb.2017.00971

El-Khier, M.K.S., Ishag, K.E.A. and Yagoub, A.E.A. (2008) 'Chemical composition and oil characteristics of sesame seed cultivars grown in 
Sudan' Res. J. Agric. and Biol. Sci. 4(6), pp. 761-766.

Elkholy, M.A., Ashly, S.E. and Gomaa, A.M. (2005) 'Biofertilizer of maize crop and its impact on yield and grain nutrient under low rates of mineral fertilizers' Journal of Applied Science Research, 2, pp, 117-121.

Elkramany, M.F., Bahr, A.A., Mohamed, F. and Kabesh, M. (2007) 'Utilization of Biofertilizers in Field Crops Production 16-Groundnut Yield, Its Components and Seeds Content as Affected by Partial Replacement of Chemical Fertilizers by Bioorganic Fertilizers' Journal of Applied Sciences Research, 3, pp. 25-29.

El-Samanody, M. K. M., El-Marsafawy, S. M., and Rehab H.K.A. (2010) 'Impact of deficit irrigation at different growth stages on some sesame varieties in Upper Egypt' $J$. Plant Production, Mansoura University, 1 (7), pp. 857 - 871.

Fakhry, S. M. K. (2016) 'Effect of mineral fertilization and some biological treatments on sesame' $P h$. D. Thesis Faculty of Agriculture Cairo University.

Hamza, M. and Abd El-Salam, R.M. (2015) 'Optimum planting date for three sesame cultivars growing under sandy soil conditions in Egypt. American-Eurasian' J. Agric. \& Environ. Sci., 15 (5), pp. 868-877.

Hasanpour, R., Pirdashti, H., Esmaeili, M.A. and Abbasian, A. (2012) 'Effect of plant growth promoting rhizobacterial (PGPR) and nitrogen on qualitative characteristics of sesame (Sesamum indicum L.) cultivars' International Journal of Agriculture and Crop Sciences. Available online at www.ijagcs.com. IJACS/2012/4-11/662-665. ISSN 2227-670X @2012 IJACS Journal

Hassaan, M. A. and Bughdady, A. M. (2018) 'Response of some sesame cultivars (Sesamum indicum L.) to bio and organic fertilizers under Toshka Conditions' J. Plant Production, Mansoura Univ., Vol. 9 (11), pp. 931 - 938.

Khalil, H.M., Abo-Basha, D.M. and ElAgyzy, F.H. (2018) 'Effect of Bacillus circulans bacteria on availability of potassium from different sources on the productivity and quality of pepper under saline soil conditions', Middle East J, 7(2), pp.339-351.

Khaled, A.S., Mona, G.A.E. and Zeinab, M.K. (2012) 'Effect of soil amendments on soil fertility and sesame crop productivity under newly reclaimed soil conditions' Journal of Applied Sciences Research, (March), pp.1568-1575.

Mahrous, N.M., Abu-Hagaza, N.M. Abotaleb, H.H. and Fakhry, S.M. (2015) 'Enhancement of growth and yield productivity of sesame plants by application of some biological treatments' American-Eurasian $J$. Agric. \& Environ. Sci., 15 (5), pp. 903-912.

Purushottam, G. (2005) 'Integrated nutrient management in sesame (Sesamum indicum L.) and its residual effect in succeeding chickpea (Cicer arietinum L.).' M.Sc. thesis, Univ. of Agric. Sci. Dharwad, India, $100 \mathrm{pp}$. 
Ryan, J., Garabet, S., Harmsen, K. and Rashid, A.A. (1996) 'Soil and Plant Analysis Manual Adapted for the west Asia and North Africa Region' ICARDA, Aleppo, Syria. 140pp.

Shehu, H.E. (2014) 'Effect of manganese and zinc fertilizers on shoot content and uptake of $\mathrm{N}, \mathrm{P}$ and $\mathrm{K}$ in sesame (Sesamum indicum L.) on Lithosols' International Research Journal of Agric. Sci. and soil Science, 4(8), pp. 159-166.

Shehu, H.E., Kwari, J.D. and Sandabe, M.K. (2010) 'Effects of N, P and K fertilizers on yield, content and uptake of $\mathrm{N}, \mathrm{P}$ and $\mathrm{K}$ by sesame (Sesamum indicum)', Int. J. Agric. Biol., 12, pp. 845-850.

Subrahmaniyan, K., Sridhar, P. and Arulmozhi, N. (1999) 'Response of sesame (Sesamum indicum) to sulphur and micronutrients with and without farmyard manure under irrigated condition' Indain J.Agron., 44(4), pp. 826-829.

Meena, V.S., Maurya, B.R. and Verma, J.P., (2014) 'Does a rhizospheric microorganism enhance $\mathrm{K}+$ availability in agricultural soils? '. Microbiological research, 169(56), pp.337-347.

Weiss, E.A. (2000) 'Oil seed Crops. $2^{\text {nd }}$ Edit' Blackwell Science, London, United Kingdom, pp: 364. 